\title{
DINAMIKA DAN KARAKTERISTIK UNIT PENANGKAPAN IKAN DI KABUPATEN PACITAN, JAWA TIMUR
}

\section{(DYNAMICS AND CHARACTERISTICS OF FISHING UNIT IN PACITAN, EAST JAVA )}

\author{
Yusuf Fathanah ${ }^{1,2}$, Eko Sri Wiyono², Darmawan², Yopi Novita ${ }^{2}$ \\ ${ }^{1}$ Corresponding author \\ ${ }^{2}$ Program Studi Sistem dan Pemodelan Perikanan Tangkap, \\ Fakultas Perikanan dan Ilmu Kelautan, Institut Pertanian Bogor \\ E-mail: yusfath@gmail.com
}

\begin{abstract}
Unit fishing and operation in Pacitan very varied, these variations complicated the management of fisheries. Understanding on fishing unit dynamic and characteritic is very important in fisheries management. The purpose of this research is to analyze characteristic of fishing unit, fishermen, fishing ground, and also to classify the fishing operational patterns. This research was conducted in February, April and May 2013 in Pacitan District, East Java Province. The data collection were conducted by personal interview and observation. The data were analysed by descriptive table and cluster analysis. The results showed that fishing activities scattered along the Pacitan coastal area. Fishing gear were operated inboard, outboard, and without engine. Outboard engine reach 84 percent from population. On the other hand, fishing gear which operated in Pacitan are traps, hooks, gillnet, seine net, purse seine, and liftnet. Using four parameters (length of ship, engine power, crews, and fishing gear) the cluster analysis resumed 6 patterns of fishing operation type. Variation of fishing patterns caused by capital ability and fishermen's skills. This research concluded that the fishing unit in Pacitan is varied and dominated by outboard engine that has 6 fishing operation patterns.
\end{abstract}

Keywords: Dynamic, charactheristic, fishing unit, Pacitan

\begin{abstract}
ABSTRAK
Unit penangkapan ikan dan pengoperasiannya di Pacitan sangat beragam. Keragamannya menyulitkan pengelolaan perikanan. Memahami dinamika dan karakteristik unit penangkapan ikan, dan pengoperasiannya diperlukan untuk keberhasilan pengelolaan perikanan. Penelitian ini bertujuan untuk menganalisis karakteristik kapal atau perahu penangkap ikan, alat penangkap ikan, nelayan, daerah penangkapan ikan, dinamika pengoperasian alat penangkap ikan, dan menentukan pengelompokkan unit penangkapan ikan.Penelitian ini dilakukan pada bulan Februari, April dan Mei 2013 di Pacitan Kabupaten, Provinsi Jawa Timur. Pengumpulan data dilakukan dengan wawancara pribadi dan observasi. Data dianalisis secara deskriptif dengan tabel, grafik, gambar, dan analisis cluster. Hasil penelitian menunjukkan bahwa kegiatan penangkapan ikan tersebar di sepanjang pesisir Pacitan. Alat penangkap ikan yang dioperasikan adalah kapal motor, perahu motor tempel, dan perahu tanpa mesin. Perahu motor tempel mencapai 84 persen dari populasi perahu di Pacitan. Di sisi lain, alat penangkap ikan yang beroperasi di Pacitan adalah perangkap, pancing, jaring insang, pukat tarik, purse seine, dan jaring angkat. Menggunakan empat parameter (panjang kapal, tenaga mesin, kru, dan alat penangkap ikan) diperoleh setidaknya 6 pola jenis operasi penangkapan ikan. Variasi pola penangkapan ikan disebabkan oleh kemampuan modal dan keterampilan nelayan. Penelitian ini menyimpulkan bahwa unit penangkapan ikan di Pacitan bervariasi dan didominasi oleh perahu motor tempel yang memiliki 6 pola operasi penangkapan ikan.
\end{abstract}

Kata kunci: Dinamika, karakteristik, unit penangkapan ikan, Pacitan

\section{PENDAhuluan}

Kegiatan penangkapan ikan di Indonesia saat ini, 90 persen didominasi oleh perikanan skala kecil (Wiyono, 2011). Menurut MConney dan Charles (2008), nelayan skala kecil beroperasi dekat dengan pantai dan menggunakan kapal penangkap ikan yang relatif kecil dan milik sendiri. Alat penangkap ikan yang digunakan oleh nelayan skala kecil adalah alat penangkap ikan tradisional, seperti jaring kecil, perangkap(bubu), pancing, jubi(tombak), dan metodemetode pengumpul dengan tangan dan beberapa yang telah dimekanisasi 
(Berkes et al, 2001). McGoodwin (2001) menambahkan bahwa perikanan skala kecil, menggunakan teknologi penangkapan yang beradaptasi terhadap perubahan daerah penangkapan dan jenis ikan targetnya. Kondisi ini menunjukkan bahwa nelayan skala kecil secara terusmenerus melakukan upaya penangkapan ikan dengan berbagai cara yang dapat dilakukan, pada lokasi penangkapan yang terbatas dan jumlah yang banyak. Apabila kondisi ini dibiarkan terus menerus, akan timbul tekanan terhadap sumberdaya perikanan di perairan pantai.

Pemanfaatan sumber daya ikan di perairan Pacitan masih di sekitar pantai dan menggunakan sarana penangkap ikan tradisional yang beragam bentuk dan jenisnya. Kapal penangkap ikan yang digunakan terdiri dari sebagian besar perahu motor tempel (PMT) yang bervariasi dimensinyadan sebagian kecil perahu tanpa motor (PTM)serta kapal motor (KM). Alat penangkapan ikan yang digunakan terdiri dari kelompok jaring insang, pancing, perangkap, pukat cicin, dan pukat tarik yang dioperasikan menggunakan teknologi yang sederhana.Terkadang dalam satu unit penangkapan menggunakan lebih dari satu jenis alat penangkap ikan. Keragaman kapal atau perahu penangkapan, alat penangkap ikan dan teknik pengoperasian yang bervariasi menyulitkan dalam mengelola perikanan khususnya perikanan skala kecil (Tzanatos et al, 2005).

Tingginya keragaman dalam perikanan skala kecil, diduga sebagai penyebab sulitnya dilakukan pengelolaan terhadap perikanan tangkap skala kecil. Oleh karena itu, perlu dilakukan kajian yang bertujuan untuk mengelola perikanan skala kecil dengan terlebih dahulu mengkaji dinamika dan karakteristik pada beberapa unit penangkapan ikan skala kecil. Tujuan penelitian ini adalah: 1)menganalisis karakteristik unit penangkapan ikan, 2) menentukan dinamika pengoperasian alat penangkap ikan, dan 3) menentukan pengelompokkan unit penangkapan ikan skala kecil di Kabupaten Pacitan.

\section{METODOLOGI}

\subsection{Waktu Penelitian dan Tempat}

Penelitian dilaksanakan pada bulan Februari dan April-Mei 2013 di Kabupaten Pacitan, Provinsi Jawa Timur. Bulan Februari dilakukan untuk memastikan kesesuaian perumusan permasalahan, tujuan penelitian, indikator kuisioner. Bulan April-Mei dilaksanakan untuk pengumpulan data primer dan observasi mendalam.

\subsection{Metode Pengumpulan Data}

Data diperoleh melalui wawancara pribadi, observasi, pengarsipan data, dan survei dengan menggunakan kuesioner. Sampel diambil secara sengaja dengan menggunakan metode purposive sampling. Responden yang dijadikan sampel sebanyak 120 orang yaitu pemilik dan nakhoda kapal atau perahu, petugas Dinas Kelautan dan Perikanan, petugas PPPTamperan, petugas tempat pelelangan ikan (TPI) Kabupaten Pacitan.

\subsection{Metode Analisis}

Data yang diperoleh dianalisis secara deskriptif yaitu dengan menyajikan tabel, dan grafik untuk menjelaskan jumlah dan distribusi unit penangkapan ikan serta profil unit penangkapan ikan. Pola operasi penangkapan dianalisis menggunakancluster analysis. Batasan dalam pengelompokkan meliputi jenis alat penangkap ikan, panjang kapal, daya mesin, dan jumlah nelayan dalam satu unit perahu penangkap ikan

\section{HASIL DAN PEMBAHASAN}

\subsection{Jumlah dan distribusi unit penangkapan ikan}

Aktivitas perikanan tangkap menyebar disepanjang pantai Pacitan. Penyebarannya meliputi 7 kecamatan dengan jumlah Pangkalan Pendaratan Ikan (PPI) mencapai 17 buah PPI. Empat kecamatan diantaranya menjadi sentra perikanan tangkap yaitu Pacitan, Kebonagung, Pringkuku, dan Ngadirojo (Tabel 1). Tahun 2007,PPI Tamperan yang berada di Kecamatan Pacitan ditingkatkan kapasitasnya menjadi Pelabuhan 
Perikanan Pantai (PPP) sehingga menjadi sentra baru perikanan tangkap.Lokasi pendaratan yang menjadi pusat aktivitas perikanan tangkap hampir sebagai besar sulit dicapai dan jauh dari pusat kota. Kondisi ini menjadi tantangan tersendiri dalam pengelolaan perikanan tangkap, sehingga peran serta nelayan dalam pengelolaan menjadi penting. Tabel 1 menunjukkan distibusi jumlah perahu dan nelayan di Pacitan.

Jumlah PMT mendominasi jumlah kapal penangkap ikan di Kabupaten Pacitan. Jumlah PMT mencapai 1.229 unit atau $84 \%$ dari seluruh jumlah kapal penangkap ikan pada tahun 2011. Sedangkan jumlah KM dan PTM memiliki jumlah lebih sedikit yaitu KM berjumlah 146 unit (10\%) dan PTM sebanyak 86 unit (6\%). Perkembangan jumlah armada penangkapan di Kabupaten Pacitan dari tahun 2003 hingga 2011 disajikan pada Gambar 1. Jumlah kapal atau perahu penangkap ikan terus bertambah selama 9 tahun terakhir. Perahu motor tempel meningkat lebih dari 1,5 kalinya pada tahun 2011 dibandingkan tahun 2003 yang hanya berjumlah 788 unit. Jumlah PMT terbanyak pada tahun 2009 yang mencapai 1260 unit dan berfluktuasi menurun sampai dengan tahun 2011. Kapal motor juga meningkat 18 kali pada tahun 2011 dibandingkan tahun 2003 yang berjumlah 8 unit. Peningkatan KM tidak terlepas dari telah beroperasinya PPP tamperan.

Jenis PMT lebih banyak digunakan nelayan di Pacitan, hal ini disebabkan kondisi perairan dan pendaratan yang tidak memungkinan untuk menggunakan kapal atau perahu lebih besar lagi. Nelayan pun lebih memilih bahan baku kapal/perahunya menggunakan fibreglass dibandingkan kayu. Kurien (2004) menegaskan bahwa yang mempengaruhi desain perahu adalah ketersediaan bahan baku dan serangkaian faktor spesifik oseanografi daerahnya, termasuk struktur, tekstur dan kemiringan dasar laut serta sifat ombak dan gelombang yang mendekati pantai.

Keberadaan KM yang sebagian besar merupakan milik nelayan pendatang, menjadi media alih teknologi sekaligus membuka arah penangkapan ikan lebih jauh dari pantai. Penangkapan jauh dari pantai memungkinkan karena dimensi KM yang lebih besar (25-30 GT), daya mesin lebih besar, dan penggunaan teknologi penangkapan yang lebih maju. Perahu motor tempel yang jumlahnya mendominasi armada penangkapan memiliki dimensi dan daya mesin yang kecil memperlihatkan kemampuan yang terbatas jarak operasi sehingga eksploitasi lebih banyak terkonsentrasi di perairan pantai. Spesifikasi teknis kapal atau perahu penangkapan ikan yang digunakan di Pacitan tercantum pada Tabel 2.

Tabel 1. Distribusi perahu dan nelayan tahun 2007-2011

\begin{tabular}{lrrrrrr}
\hline \multirow{2}{*}{ Kecamatan } & \multicolumn{4}{c}{ Perahu } & \multicolumn{4}{c}{ Nelayan } \\
\cline { 2 - 7 } & 2007 & 2011 & $\begin{array}{c}\text { Pertumbuhan } \\
(\%)\end{array}$ & 2007 & 2011 & $\begin{array}{c}\text { Pertumbuhan } \\
(\%)\end{array}$ \\
\hline Donorojo & 1 & 7 & 109,17 & 123 & 125 & 0,41 \\
Pringkuku & 108 & 218 & 22,01 & 619 & 681 & 2,48 \\
Pacitan & 265 & 396 & 12,05 & 1427 & 1413 & 0,94 \\
Kebonagung & 280 & 327 & 4,18 & 742 & 754 & 0,40 \\
Tulakan & 57 & 59 & 8,61 & 118 & 164 & 9,75 \\
Ngadirojo & 214 & 365 & 15,64 & 447 & 470 & 1,45 \\
Sudimoro & 91 & 101 & 4,39 & 270 & 233 & $-3,47$ \\
\hline
\end{tabular}




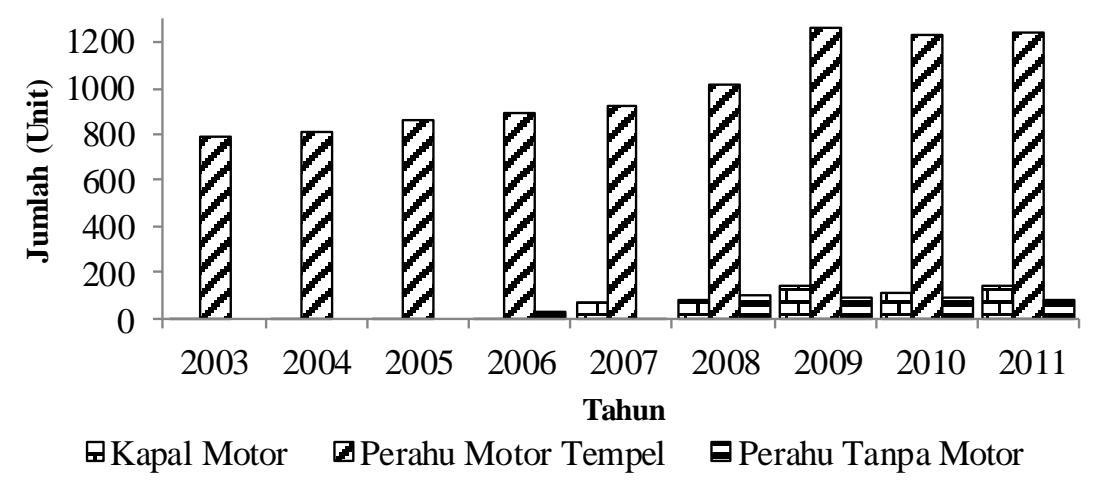

Gambar 1. Jumlah perahu tanpa motor $(\mathbf{\Lambda})$, perahu motor tempel $(\diamond)$ dan kapal motor(X)

Tabel 2. Spesifikasi teknis kapal/perahu penangkapan ikan

\begin{tabular}{|c|c|c|c|c|c|c|c|}
\hline \multirow{2}{*}{ No } & \multirow{2}{*}{ Kapal/perahu } & \multirow{2}{*}{ Jenis } & \multicolumn{3}{|c|}{ Dimensi (m) } & \multirow{2}{*}{ Material } & \multirow{2}{*}{$\begin{array}{l}\text { Kekuatan } \\
\text { mesin }\end{array}$} \\
\hline & & & LOA & $\mathrm{B}$ & $\mathrm{D}$ & & \\
\hline 1 & $\begin{array}{l}\text { Kapal purse } \\
\text { seine }\end{array}$ & KM & $16-19$ & 6 & $2-3$ & $\begin{array}{l}\text { kayu/ } \\
\text { fibre }\end{array}$ & 185-280 HP \\
\hline 2 & Kapal Tonda & KM & $16-17$ & $3-3.5$ & $1-2$ & Kayu & 2x30 HP \\
\hline 3 & $\begin{array}{l}\text { Daplangan/ } \\
\text { Jukung }\end{array}$ & PMT & $7-13$ & $\begin{array}{l}0.7- \\
1.5\end{array}$ & $\begin{array}{l}0.5- \\
1.1\end{array}$ & fibre & 8-15 HP \\
\hline 4 & Mancung & PTM & $3-4$ & $0.6-1$ & $\begin{array}{l}0.3- \\
0.5\end{array}$ & Kayu & \\
\hline
\end{tabular}

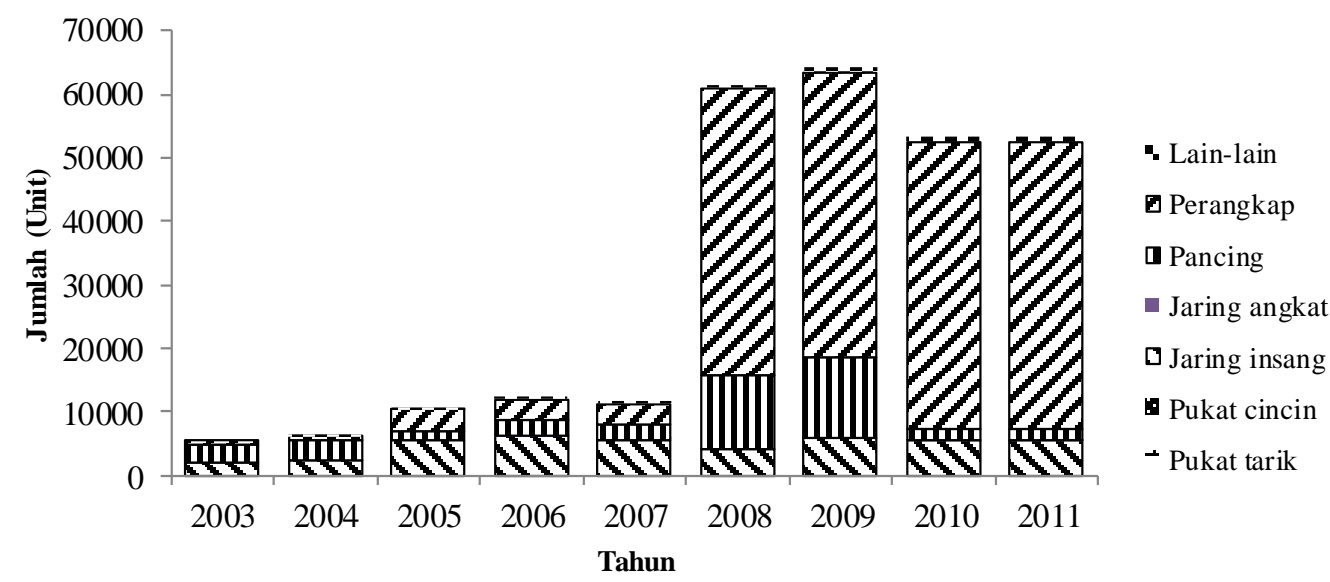

Gambar 2. Komposisi alat penangkap ikan

Jenis alat penangkapan ikan yang digunakan oleh armada penangkapan di Kabupaten Pacitan adalah kelompok perangkap, pancing, jaring insang, pukat tarik, pukat cincin, jaring angkat, dan lainnya. Tahun 2011 jumlah kelompok perangkap (krendet) mencapai 85\% dibandingkan kelompok alat penangkap ikan yang lain. Sedangkan kelompok jaring insang yang terdiri dari jaring insang hayut, jaring klitik, jaring insang tetap, dan jaring tiga lapis berjumlah $10 \%$. Sisanya terdiri dari Kelompok pancing (pancing rawai dan pancing ulur) $3.16 \%$, pukat tarik (payang dan dogol) 
$0.14 \%$, pukat cicin $0.04 \%$ dan lainnya $1.04 \%$ (Gambar 2).

Alat penangkap ikan yang digunakan didominasi oleh alat penangkap ikan yang sederhana, mudah dioperasikan, murah, dan mudah didapat serta spesifik menangkap target spesies tertentu, seperti krendet untuk menangkap udang lobster dan gillnet hanyut untuk menangkap tongkol. Metode operasi penangkapannya pun masih menggunakan tenaga nelayan secara langsung dan belum menggunakan alat mekanis untuk membantu penangkapan kecuali pada purse seine yang sudah menggunakan 'gardan' untuk membantu menarik tali kerut. Kurien (2004) mengungkapkan bahwa konstruksi, bahan dan desain alat penangkap ikan yang digunakan adalah hasil dari proses adaptasi penangkapan ikan selama berabad-abad.

Nelayan di Kabupaten Pacitan kebanyakan merupakan nelayan lokal dan sedikit nelayan andon (Gambar 3). Sebagian besar nelayan lokal berdomisili tidak jauh dari PPI atau alur sungai tempat menambatkan perahunya. Jumlah nelayan lokal mengalami kecenderungan menurun dalam 9 tahun terakhir. Nelayan lokal di Kabupayen Pacitan terdiri dari nelayan tetap, nelayan sambilan, dan nelayan kadang-kadang. Tahun 2011, nelayan tetap berjumlah 1923 orang $(68 \%), 620$ orang $(22 \%)$ nelayan sambilan dan $271(10 \%)$ nelayan kadang-kadang. Nelayan tetap umumnya adalah nelayan pemilik perahu atau orang yang dipercaya pemilik kapal untuk menjalankan perahu (juru mudi). Sedangkan nelayan sambilan dan kadang-kadang umumnya adalah anak buah kapal.
Nelayan andon yang berasal dari daerah lain di luar Kabupaten Pacitan berjumlah 1026 orang (27\% tahun 2011). Kebanyakan nelayan andon berasal dari Pekalongan, Kalimantan, Sulawesi, dan Nusa Tenggara Timur dan umumnya mengoperasikan alat penangkap ikan pancing dan pukat cincin. Keberadaan nelayan andon terkonsentrasi hanya di PPP Tamperan dan tinggal di beberapa rumah singgah yang disediakan oleh PPP Tamperan.

Jumlah nelayan lokal lebih dominan dibandingkan nelayan pendatang. Nelayan tersebar di sepanjang pantai Pacitan dengan konsentrasi paling banyak berada di sekitar Teluk Pacitan. Jumlah nelayan lokal semakin menurun beberapa tahun terakhir. Penurunan ini akibat dari semakin sulitnya mendapatkan hasil tangkapan yang cukup untuk penghidupan nelayan sehari-hari. Kesulitan mendapatkan ikan ini pun dibuktikan dengan terjadinya konflik antar nelayan dalam aktifitas menangkap ikan. Nelayan yang mampu bertahan dalam penangkapan umumnya memiliki aktivitas lain untuk memenuhi kebutuhan mereka, diantaranya yaitu bertani, berkebun, dan buruh panggul di PPP Tamperan.

Jumlah PMT dengan ukuran relatif kecil dan alat penangkap ikan yang beragam, menggambarkan bahwa daerah penangkapan ikan yang dekat dengan pantai dan pesisir. Carvalho et al (2011) menjelaskan bahwa perikanan skala kecilmemiliki potensi besar untuk mencip-takan kelebihan kapasitas dan eksploi-tasi berlebihan terhadap sumber daya pesisir karena ukuran kapal yang kecil telah membatasi kegiatan mereka hanya di daerah penangkapan yang terbatas. 


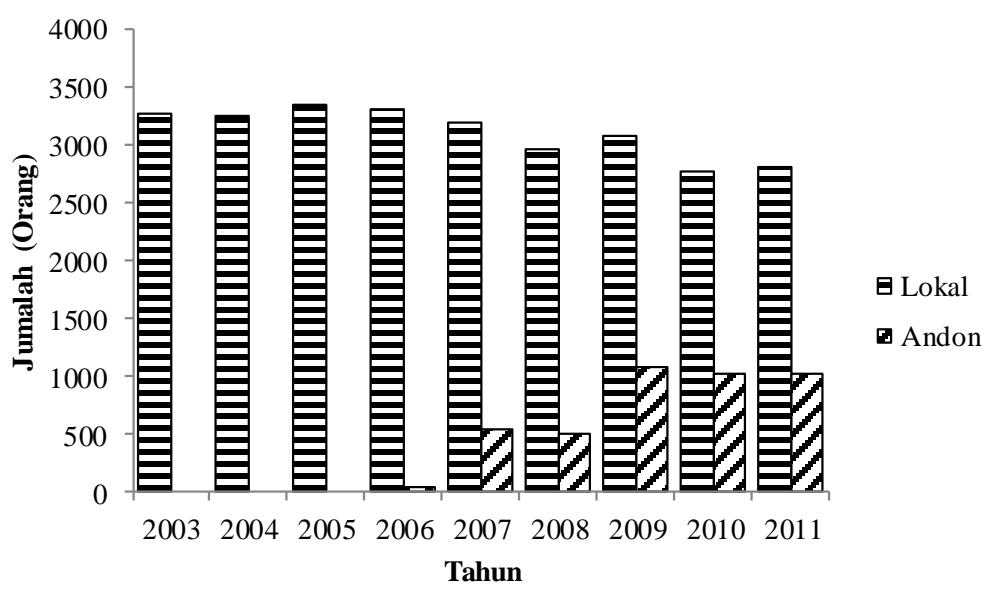

Gambar 3. Jumlah Nelayan Kabupaten Pacitan

Selanjutnya Kurien (2006) menyebutkan bahwa biaya operasi yang rendah juga membatasi nelayan dalam operasi penangkapan. Berdasarkan ploting daerah penangkapan yang pernah dikunjungi nelayan terlihat bahwa 1-4 mil yang paling padat. Pada area ini nelayan banyak mengoperasikan krendet, jaring klitik, payang, dogol, dan rawai dasar. Konflik penggunaan alat penangkap ikan sering terjadi pada area ini. Area lebih dari 4 mil merupakan daerah operasi penangkapan untuk pancing rawai hanyut dan jaring insang hanyut.

\subsection{Dinamika pengoperasian alat penangkap ikan}

Waktu penangkapan PMT dan PTM dimulai pada pagi hari antara pukul 2.30-04.00 dan pulang pada siang hari antara pukul 10.00-12.00. Strategi nelayan dalam operasi penangkapan cukup bervariasi. Pengoperasian jenis alat penangkap ikan dalam suatu waktu operasi penangkapan berbeda-beda (Gambar 5). Pada musim penghujan, dimana krustasea dan ikan demersal sedang musim, nelayan banyak mengoperasikan alat penangkap ikan krendet, trammel net dan jaring insang bawal. Sedangkan pada musim kemarau, saat kondisi perairan berombak kecil, hampir sebagian besar nelayan mengoperasikan jaring insang tongkol yang daerah operasinya lebih jauh dari pantai.

Kombinasi pengoperasian alat penangkap ikan sering dilakukan oleh nelayan kecil di Pacitan. Kombinasi biasanya terdiri dari 2 alat yang berbeda cara pengoperasiannya. Alat penangkap ikan yang pasif atau semi pasif seperti jaring insang tetap, jaring insang hanyut, rawai tetap, dan krendet dengan alat penangkap ikan yang aktif seperti payang, dogol dan pancing ulur. Hasil penelitian menunjukkan 59 persen dari 56 responden yang menjawab mengkombinasikan alat penangkap ikan gillnet dengan pancing, 34\% mengkombinasikan alat penangkap ikan payang dan jaring insang dan $7 \%$ mengkombinasikan dogol dengan jaring insang dalam 1 trip penangkapan.

Penggunaan alat penangkap ikan yang beragam memungkinkan PMT beroperasi sepanjang tahun dengan menyesuaikan kondisi dan target spesies tertentu. Salas et al (2004) mengungkapkan bahwa nelayan dalam menangkap ikan, akan memilih ikan targetspesies dan daerah penangkapan berdasarkan informasi yang dikumpulkan sebelumnya meliputi ketersediaan spesies (berdasarkan pengetahuan nelayan), tentang perilaku ikan dan hasil tangkapan yang diperoleh sendiri dan nelayan yang lain. Alat penangkap ikan yang digunakan nelayan skala kecil pada umumnya pasif, selektif, digunakan tertentu disesuaikan musim tertentu (Kurien, 2004).

Alat penangkap ikan di Pacitan terdiri dari kelompok jaring lingkar, perangkap, jaring insang, pancing, dan pukat tarik. Kombinasi alat penangkap ikan yang digunakan KM terbagi atas KM yang menggunakan pukat cincin dan KM yang menggunakan pancing (tonda). Perahu tanpa motor umumnya hanya 
menggunakan jaring insang, pancing dan perangkap. Adapun PMT memiliki keragaman yang tinggi berdasarkan jenis alat penangkap ikan (api) yang dioperasikan. Hasil observasi lapang dan pengelompokkan terhadap data responden di peroleh 8 kelompok kombinasi alat penangkap ikan yang digunakan (Tabel 3). Seilert dan Sangchan (2001) membuktikan bahwa kombinasi jenis alat penangkap ikan pada perikanan skala kecil, misalnya trammel netdan gillnet makarel, meningkatkan jumlah total pendapatan yang rumah tangga nelayan skala kecil.

\subsection{Pola operasi penangkapan ikan}

Pengelompokkan operasi penangkapan ikan dengan variabel panjang kapal, daya mesin, jumlah ABK, dan kelompok alat penangkap ikan pada PMT menunjukkan bahwa jenis usaha penagkapan dapat dikelompokkan menjadi 6 kelompok (Gambar 4). Karakteristik masing-masing kelompok jenis usaha penangkapan PMT berbeda-beda (Tabel 4). Kelompok usaha I, merupakan kelompok pola operasi penangkapan yang banyak (64\%) digunakan oleh nelayan responden. Sedangkan kelompok usaha VI adalah kelompok yang paling sedikit digunakan (1\%). Perbedaan mencolok pada kelompok usaha VI dan kelompok usaha I adalah pada panjang kapal.

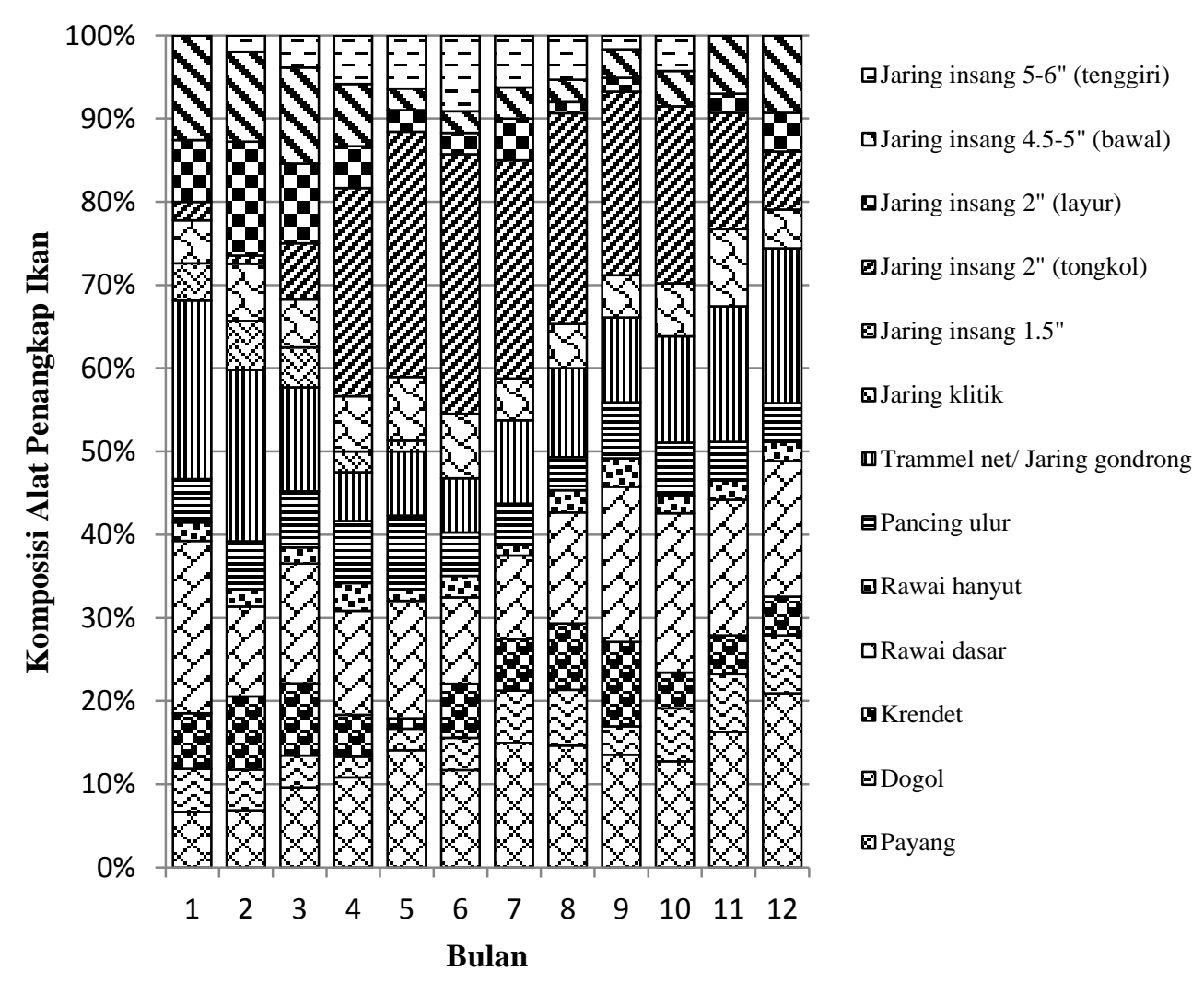

Gambar 4. Komposisi jumlah pengoperasian alat penangkap ikan

Tabel 3. Kelompok kombinasi alat penangkap ikan

\begin{tabular}{clr}
\hline Kelompok & \multicolumn{1}{c}{ Alat Penangkap Ikan } & Komposisi (\%) \\
\hline api 1 & Pancing, jaring insang, perangkap & $25 \%$ \\
api 2 & Pancing, jaring insang & $24 \%$ \\
api 3 & Pancing, jaring insang, pukat tarik & $15 \%$ \\
api 4 & Pukat tarik & $11 \%$ \\
api 5 & Jaring insang, pukat tarik & $9 \%$
\end{tabular}


api $6 \quad$ Jaring insang

Daya mesin yang digunakan memberikan gambaran terhadap jarak operasi dan alat penangkap ikan yang digunakan. Kapal motor (KM) yang beroperasi lebih jauh dari pantai umumnya menggunakan daya 30 horsepower (HP) yang terdiri dari 2 mesin untuk pancing tonda dan 280 HP untuk pukat cincin. Kapal motor "sekoci" dan pukat cincin memiliki lama trip penangkapan 7-10 hari. Daya mesin yang digunakan PMT bervariasi menyesuaikan alat penangkap ikan, jarak daerah penangkapan dan kemampuan modal nelayan. Perahu motor tem-

Tabel 4. Hasil pegelompokkan jenis usaha penangkapan berdasarkan alat penangkap ikan yang digunakan pel menggunakan menggunakan 3 jenis mesin dengan daya $5.5 \mathrm{HP}, 8.5 \mathrm{HP}$, dan $15 \mathrm{HP}$, beroperasi dengan durasi 6-9 jam dalam 1 trip penangkapan. Observasi menujukkan sebagian besar nelayan dengan modal yang besar akan memiliki kapal penangkap ikan lebih besar dan kuat, dan jenis alat tagkap lebih lengkap dibandingkan nelayan yang bermodal kecil. Nelayan yang memiliki modal kecil lebih memilih alat penangkap ikan seperti perangkap, jaring insang dan pancing.

\begin{tabular}{llcll}
\hline Kelompok & Panjang $(\mathrm{m})$ & Daya (PK) & ABK(org) & Alat Penangkap Ikan \\
\hline Usaha 1 & $7-12$ & 15 & $2-4$ & api 1, api 2, api 3, api 4 \\
Usaha 2 & $7-9$ & $6-8.5$ & $2-4$ & api 2, api 4, api 5, api 7 \\
Usaha 3 & $4-4.5$ & $6-8$ & $3-4$ & api 1, api 4, api 7 \\
Usaha 4 & $7-9$ & 15 & $2-3$ & api 5, api 6, api 7 \\
Usaha 5 & $8-9$ & $6.5-8$ & 3 & api 6, api 8 \\
Usaha 6 & 4 & 15 & 3 & api 1 \\
\hline
\end{tabular}

Le Pape dan Vigneau (2001) mengungkapkan bahwa karakteristik teknis kapal (panjang total, kapasitas, dan tenaga kuda) serta ukuran kru merupakan faktor yang secara signifikan mempengaruhi usaha penangkapan ikan. Jenis kapal/perahu dan alat penangkap ikan yang digunakan menggambarkan bentuk pola operasi penangkapan ikan nelayan Pacitan. Berdasarkan kapal/perahu yang digunakan pola operasi penangkapan terbagi menjadi tiga, yaitu kelompok yang menggunakan kapal motor (KM), perahu motor tempel (PMT) dan perahu tanpa motor (PTM). Alat penangkap ikan secara khusus membedakan antara ketiganya, dimana KM menggunakan satu jenis alat penangkap ikan (single gear) sedangkan PMT dan PTM menggunakan lebih dari satu jenis alat penangkap ikan (multi gear). Hasil pengelompokkan menunjukkan variasi terbesar kelompok PMT, yakni 6 kelompok dengan ciri khas masing-masing antar kelompok. Pemilihan panjang perahu, daya mesin, anak buah kapal dan alat penangkap ikan yang digunakan menunjukan bagaimana nelayan melakukan strategi penangkapan yang disesuaikan dengan kemampuannya. Nelayan yang memiliki modal dan keahlian yang lebih banyak akan mampu mengkombinasikan alat penangkap ikannya dengan lebih beragam.

\section{KESIMPULAN}

\subsection{Kesimpulan}

1. Aktivitas penangkapan ikan oleh nelayan skala kecil di Pacitan tersebar sepanjang pantai Pacitan. Jenis ka$\mathrm{pal} /$ perahu penangkapan yang dominan digunakan adalah perahu motor tempel (PMT) dan sebagian kecil kapal motor (KM) serta perahu tanpa motor (PTM). Alat penangkap ikan yang digunakan beragam meliputi perangkap, pancing, jaring insang, pukat tarik, pukat cincin, dan jaring angkat.

2. Dinamika pengoperasian alat penangkap ikan dipengaruhi oleh musim, 
ikan target penangkapan, dan daerah penangkapanya.

3. Perahu motor tempel dikelompokkan menjadi 6 kelompok berdasarkan panjang kapal, daya mesin,jumlah ABK dan alat penangkap ikan yang digunakan. Variasi operasi penangkapan disebabkan kemampuan modal danketerampilan nelayan.

\subsection{Saran}

1. Perlu dilakukan penelitian tentang spesifikasi teknis kapal penangkap ikan khususnya PMT yang efisien untuk penangkapan ikan dengan kondisi geografis pantai selatan Jawa.

2. Perlu dilakukan penelitian dinamika operasi penangkapan terhadap perubahan kondisi ekonomi (seperti perubahan harga BBM dan kurs Rupiah terhadap Dollar).

\section{DAFTAR PUSTAKA}

Berkes F, Mahon R, McConney P, Pollnac R, dan Pomeroy R. 2001. Mengelola Perikanan Skala Kecil Arah dan Metode Alternatif. Kanada.

[BPS] Badan Pusat Statistik. 2012. Kabupaten Pacitan dalam Angka 2012. Pacitan (ID): BPS.

Carvalho N, Jones GE, Isidro E. 2011. Defining scale in fisheries: Small versus large-scale fishing operations in the Azores. Fisheries Research. 109: 360-369 doi:10.1016/j.fishres.2011.03.006.

Kurien J., 2006. Overcapacity, overfishing and subsidies:howdo they relate to smallscale fisheries? In: Presented at the 8th Pacific Rim Fisheries Conference, Hanoi, 22-24 March.

Kurien J, 2004. The Blessing of Commons: Small Scale Fisheries, Community Property Rights, and Coastal Natural Assets. Political Economy Research Institur. University of Massachusetts Amherest.

Le Pape O, Vigneau J, 2001. The influence of vessel size and fishing strategy on the fishing effort for multispecies fisheries in northwestern France. ICES J. Mar. Sci. 58, 1232-1242.

McConney, Charles A. 2008. Managing Small-Scale Fisheries: Moving Towards People-Centred Perspectives.
Handbook of Marine Fisheries Conservation and Management. 1-2 hal.http://husky1.stmarys.ca/ cha rles/PDFS_2005/059.pdf.

McGoodwin JR. 2001. Understanding the cultures of fishing communities. A Key to fisheries management and food security. Roma. FAO.

Salas S, Sumaila UR, Pitcher T. 2004. Short-term decisions of small-scale fishers selecting alternative target species: a choice model. CanadianJournal Fisheries Aquatic Science. 61:374-383. doi: 10.1139/F04-007.

Salayo ND, Ahmed M, Garces L. and Viswanathan K. 2006. An Overview of Fisheries Conflicts in South and Southeast Asia: Recommendations, Challenges and Directions.NAGA, WorldFish Center Quarterly Vol. 29 No. 1 \& 2 Jan-Jun 2006.

Seilert H, Sengchan S. 2001. Small-Scale Fishery In Southeast Asia: A Case Study In Southern Thailand. Thailand. FAO.

Tzanatos E, Dimitriou E, Katselis G, Georgiadis M, Koutsikopoulos C. 2005. Composition, temporal dynamics and regional characteristics of smallscale fisheries in Greece. Fish. Res. 73: 147-158.

Wiyono, ES. 2011.Reorientasi Manajemen Perikanan Skala Kecil.New Paradigm in Marine Fisheries: Pemanfaatan dan Pengelolaan Sumberdaya Perikanan Laut Berkelanjutan. Nurani TW, Simbolon D, Solihin A, Yuniarta S, editor. Bogor (ID). Intramedia. 